\title{
GAMBARAN KECEMASAN PASIEN EKSTRAKSI GIGI SEBELUM DAN SESUDAH MENGHIRUP AROMATERAPI LAVENDER
}

\author{
${ }^{1}$ Merinchiana \\ ${ }^{2}$ Hendri Opod \\ ${ }^{3}$ Jimmy Maryono
}

\author{
${ }^{1}$ Kandidat Skripsi Program Studi Pendidikan Dokter Gigi Fakultas Kedokteran \\ ${ }^{2}$ Bagian Psikologi Fakultas Kedokteran Universitas Sam Ratulangi \\ ${ }^{3}$ Program Studi Pendidikan Dokter Gigi Fakultas Kedokteran \\ Universitas Sam Ratulangi Manado \\ E-mail: mee.chiana@gmail.com
}

\begin{abstract}
Anxiety due tooth extraction can causes obstacles for the operators and it delivers several problems. To overcome this anxiety, a consideration treatment is required, to settle anxiety experienced by patients. One of the solutions is to inhale lavender aromatherapy. Essensial oil of lavender can affect the brain activity through nerve system related to sense of smell and it connects with psychology condition such as emotional. This study aimed to describe the anxiety of patients with tooth extraction before and after inhaling lavender aromatherapy. This was a descriptive study with a cross sectional design. There were 30 respondents who are going to be undergone tooth extraction. Physical evaluation such as blood pressure, pulse, and respiration, and Visual analogue scale (VAS) for measureing anxiety were used. The results showed that patients had lower blood pressure, pulse, respiration as well as VAS after they inhaled lavender aromatherapy. Conclusion: Patients who were going to undergo tooth extraction had declined anxiety after inhalation of Lavender aromatherapy.
\end{abstract}

Keywords: tooth extraction, anxiety, visual analogue scale, lavender aromatherapy

\begin{abstract}
Abstrak: Kecemasan karena ekstraksi gigi dapat menjadi penghambat bagi operator dan menimbulkan banyak masalah. Untuk mengatasi masalah kecemasan diperlukan pertimbangan perawatan yang dapat menanggulangi kecemasan yang dialami pasien salah satu diantaranya dengan menghirup aromaterapi lavender. Minyak esensial lavender dapat memengaruhi aktivitas fungsi kerja otak melalui saraf yang berhubungan dengan indera penciuman dan berkaitan dengan kondisi psikologis seperti emosi. Penelitian ini bertujuan untuk mengetahui gambaran kecemasan pasien ekstraksi gigi sebelum dan sesudah menghirup aromaterapi lavender. Jenis penelitian deskriptif dengan rancangan penelitian potong lintang dilakukan pada 30 responden yang akan menjalani prosedur ekstraksi gigi dengan menggunakan evalusi fisik berupa tekanan darah, nadi, dan respirasi, serta visual analogue scale (VAS) untuk mengukur kecemasan. Hasil penelitian menunjukkan bahwa tekanan darah, nadi, dan respirasi serta VAS pasien yang cemas mengalami penurunan setelah menghirup aromaterapi lavender. Simpulan: Kecemasan pasien ekstraksi gigi mengalami penurunan setelah menghirup aromaterapi lavender.
\end{abstract}

Kata kunci: ekstraksi gigi, kecemasan, visual analogue scale, aromaterapi lavender

Prosedur ekstraksi atau pencabutan gigi merupakan satu dari sekian banyak perawatan gigi yang sering dilakukan oleh tenaga kesehatan gigi. Meskipun sering dilakukan, pasien ekstraksi gigi umumnya mengalami kecemasan. Takut terhadap dokter gigi merupakan salah satu faktor yang dapat menimbulkan perasaan cemas, 
selain itu penggunaan alat tajam seperti jarum suntik, tang, dan bein pada saat ekstraksi juga merupakan faktor yang menimbulkan rasa cemas. Rasa cemas merupakan emosi normal manusia yang sering dialami setiap orang. Perasaan tersebut ditandai oleh rasa khawatir yang tidak menyenangkan dan samar-samar. Kecemasan seringkali menjadi alasan seseorang untuk menghindari ekstraksi gigi dan pasien yang mengalami kecemasan akan sangat sulit memiliki sikap kooperatif selama dilakukannya tindakan ekstraksi.

Kecemasan yang timbul akibat ekstraksi gigi dianggap bukan merupakan masalah kesehatan yang serius melainkan hanya menjadi hambatan bagi tenaga kesehatan gigi dalam usaha untuk meningkatkan kesehatan gigi dan mulut, tetapi kecemasan yang dialami oleh pasien dapat menimbulkan beberapa masalah, misalnya pasien mungkin mengambil sikap tegang, kewaspadaan yang berlebihan, tangan dan kaki gemetar, banyak bicara, pupil membesar, memberikan gambaran dari ketakutan yang tak dikendalikan, kedua tangan dan muka berkeringat berlebihan. Bahkan dalam kondisi yang sangat akut, pasien mungkin akan mengalami reaksi generalized visceral pada pernafasan, jantung, pembuluh darah, gangguan fungsi pencernaan, histeria, bahkan sampai mengalami syok. ${ }^{1}$

Untuk mengatasi masalah kecemasan diperlukan pertimbangan perawatan yang dapat menanggulangi kecemasan yang dialami oleh pasien. Banyak cara telah ditempuh untuk mengatasi kecemasan antara lain dengan pendekatan psikodinamika, humanistik, pendekatan belajar, dan pendekatan biologis. Salah satu cara yang paling sering digunakan yaitu pendekatan biologis, dalam hal ini farmakoterapi tetapi efek samping yang mungkin dapat ditimbulkan obat-obatan tersebut menjadi suatu pertimbangan.

Salah satu alternatif yang patut dicoba ialah dengan aromaterapi. Aromaterapi merupa-kan salah satu teknik perawatan menggunakan wewangian yang berasal dari minyak esensial aromaterapi. Minyak essensial diperoleh melalui ekstrak dari bunga, daun, batang, dan akar baik itu melalui direbus, dikukus, maupun yang diuapkan. Salah satu aroma yang paling digemari ialah lavender. Minyak esensial lavender dipercaya memiliki kandungan utama yang dapat mempengaruhi aktivitas fungsi kerja otak melalui sistem saraf yang berhubungan dengan indera penciuman dan berkaitan dengan pemulihan kondisi psikologis seperti emosi, perasaan, pikiran, dan keinginan. ${ }^{2}$

Menurut hasil dari beberapa penelitian seperti: pengaruh aromaterapi terhadap tingkat kecemasan sebelum operasi dengan anastesi spinal; ${ }^{3}$ dan pengaruh aromaterapi lavender terhadap derajat kecemasan pada lansia ${ }^{4}$, diperoleh kesimpulan bahwa minyak essensial dari aromaterapi lavender dapat memberikan manfaat relaksasi, mengurangi tingkat kecemasan dan mampu memperbaiki mood seseorang. Uraian di atas menjadi dasar penulis untuk melakukan penelitian mengenai gambaran kecemasan pasien yang akan dilakukan ekstraksi gigi sebelum dan sesudah menghirup aromaterapi lavender.

\section{METODE PENELITIAN}

Penelitian ini menggunakan metode deskriptif dengan pendekatan potong lintang. Jumlah sampel yang diteliti sebanyak 30 orang yang berusia 17-65 tahun, dengan teknik pengambilan sampel menggunakan total sampling. Sebelum menjalani ekstraksi gigi, evaluasi fisik berupa tekanan darah, denyut nadi, dan respirasi dilakukan pada pasien kemudian pasien mengisi formulir pemeriksaan Visual Analogue Scale (VAS) untuk mengukur kecemasan pasien sebelum menghirup menjalani ekstraksi gigi, evaluasi fisik berupa tekanan darah, denyut nadi, dan respirasi dilakukan pada pasien.

Pasien mengisi formulir pemeriksaan VAS untuk mengukur kecemasan pasien sebelum menghirup aromaterapi lavender, kemudian pasien akan menjalani ekstraksi gigi sambil menghirup aromaterapi lavender dalam bentuk lilin aromaterapi yang sudah dinyalakan sebelumnya dan 
minyak essensial aromaterapi lavender yang sudah disemprotkan di ruang perawatan.

Setelah prosedur ekstraksi gigi selesai dilaksanakan, evalusi fisik dan pengisian VAS kembali dilakukan untuk mengukur kecemasan pasien setelah menhirup aromaterapi lavender. Setelah memperoleh semua data yang diperlukan, data diolah dan disajikan berdasarkan distribusi frekuensi dalam bentuk tabel.

\section{HASIL PENELITIAN}

Tabel 1. Distribusi gambaran kecemasan pasien yang belum pernah menjalani prosedur ekstraksi gigi berdasarkan pengukuran tekanan darah

\begin{tabular}{|c|c|c|c|c|}
\hline \multirow{3}{*}{ Kategori } & \multicolumn{4}{|c|}{$\begin{array}{c}\text { Pemeriksaan fisik } \\
\text { Pengukuran tekanan darah }\end{array}$} \\
\hline & \multicolumn{2}{|c|}{$\begin{array}{c}\text { Sebelum } \\
\text { menghirup } \\
\text { aromaterapi }\end{array}$} & \multicolumn{2}{|c|}{$\begin{array}{c}\text { Sesudah } \\
\text { menghirup } \\
\text { aromaterapi }\end{array}$} \\
\hline & $\mathrm{n}$ & $\%$ & $n$ & $\%$ \\
\hline Tinggi & 0 & 0 & 0 & 0 \\
\hline Normal & 11 & 100 & 11 & 100 \\
\hline Rendah & 0 & 0 & 0 & 0 \\
\hline Total & 11 & 100 & 11 & 100 \\
\hline
\end{tabular}

Tabel 2. Distribusi gambaran kecemasan pasien yang pernah menjalani prosedur ekstraksi gigi berdasarkan pengukuran tekanan darah

\begin{tabular}{ccccc}
\hline & \multicolumn{3}{c}{$\begin{array}{c}\text { Pemeriksaan fisik pengukuran } \\
\text { tekanan darah }\end{array}$} \\
\cline { 2 - 5 } Kategori & $\begin{array}{c}\text { Sebelum } \\
\text { menghirup } \\
\text { aromaterapi }\end{array}$ & $\begin{array}{c}\text { Sesudah } \\
\text { menghirup } \\
\text { aromaterapi }\end{array}$ \\
\cline { 2 - 5 } & $\mathrm{n}$ & $\%$ & $\mathrm{n}$ & $\%$ \\
\hline Tinggi & 2 & 10,5 & 2 & 10,5 \\
Normal & 17 & 89,5 & 17 & 89,5 \\
Rendah & 0 & 0 & 0 & 0 \\
Total & 19 & 100 & 19 & 100 \\
\hline
\end{tabular}

Tabel 3. Distribusi gambaran kecemasan pasien yang belum pernah menjalani prosedur ekstraksi gigi berdasarkan pengukuran denyut nadi

\begin{tabular}{ccc}
\hline \multirow{2}{*}{ Kategori } & \multicolumn{2}{c}{$\begin{array}{c}\text { Pemeriksaan fisik pengukuran } \\
\text { nadi }\end{array}$} \\
\cline { 2 - 3 } & Sebelum & Sesudah \\
\hline
\end{tabular}

\begin{tabular}{ccccc} 
& \multicolumn{2}{c}{$\begin{array}{c}\text { menghirup } \\
\text { aromaterapi }\end{array}$} & \multicolumn{2}{c}{$\begin{array}{c}\text { menghirup } \\
\text { aromaterapi }\end{array}$} \\
\cline { 2 - 5 } & $\mathrm{n}$ & $\%$ & $\mathrm{n}$ & $\%$ \\
\hline Tinggi & 2 & 18,2 & 1 & 9,1 \\
Normal & 9 & 81,8 & 10 & 90,9 \\
Rendah & 0 & 0 & 0 & 0 \\
Total & 11 & 100 & 11 & 100 \\
\hline
\end{tabular}

Tabel 4. Distribusi gambaran kecemasan pasien yang pernah menjalani prosedur ekstraksi gigi berdasarkan pengukuran denyut nadi

\begin{tabular}{ccccc}
\hline & \multicolumn{2}{c}{$\begin{array}{c}\text { Pemeriksaan fisik pengukuran } \\
\text { nadi }\end{array}$} \\
\cline { 2 - 5 } Kategori & $\begin{array}{c}\text { Sebelum } \\
\text { menghirup } \\
\text { aromaterapi }\end{array}$ & $\begin{array}{c}\text { Sesudah } \\
\text { menghirup } \\
\text { aromaterapi }\end{array}$ \\
\cline { 2 - 5 } & $\mathrm{n}$ & $\%$ & $\mathrm{n}$ & $\%$ \\
\hline Tinggi & 6 & 31,6 & 3 & 15,8 \\
Normal & 13 & 68,4 & 16 & 84,2 \\
Rendah & 0 & 0 & 0 & 0 \\
Total & 19 & 100 & 19 & 100 \\
\hline
\end{tabular}

Tabel 5. Distribusi gambaran kecemasan pasien yang belum pernah menjalani prosedur ekstraksi gigi berdasarkan pengukuran respirasi

\begin{tabular}{ccccc}
\hline & \multicolumn{3}{c}{$\begin{array}{c}\text { Pemeriksaan fisik pengukuran } \\
\text { respirasi }\end{array}$} \\
\cline { 2 - 5 } Kategori & \multicolumn{2}{c}{ Sebelum } & \multicolumn{2}{c}{ Sesudah } \\
& menghirup & \multicolumn{2}{c}{ menghirup } \\
& aromaterapi & \multicolumn{2}{c}{ aromaterapi } \\
& $\mathrm{n}$ & $\%$ & $\mathrm{n}$ & $\%$ \\
\hline Tinggi & 5 & 45,5 & 4 & 36,4 \\
Normal & 6 & 54,5 & 7 & 63,6 \\
Rendah & 0 & 0 & 0 & 0 \\
Total & 11 & 100 & 11 & 100 \\
\hline
\end{tabular}

Tabel 6. Distribusi gambaran kecemasan pasien yang pernah menjalani prosedur ekstraksi gigi berdasarkan pengukuran respirasi

\begin{tabular}{|c|c|c|c|c|}
\hline \multirow{3}{*}{ Kategori } & \multicolumn{4}{|c|}{$\begin{array}{l}\text { Pemeriksaan fisik pengukuran } \\
\text { respirasi }\end{array}$} \\
\hline & \multicolumn{2}{|c|}{$\begin{array}{c}\text { Sebelum } \\
\text { menghirup } \\
\text { aromaterapi }\end{array}$} & \multicolumn{2}{|c|}{$\begin{array}{c}\text { Sesudah } \\
\text { menghirup } \\
\text { aromaterapi }\end{array}$} \\
\hline & $\mathrm{n}$ & $\%$ & $\mathrm{n}$ & $\%$ \\
\hline Tinggi & 11 & 57,9 & 7 & 36,8 \\
\hline Normal & 7 & 36,8 & 12 & 63,2 \\
\hline Rendah & 1 & 5,3 & 0 & 0 \\
\hline Total & 19 & 100 & 19 & 100 \\
\hline
\end{tabular}

Tabel 7. Distribusi gambaran kecemasan pasien yang belum pernah menjalani prosedur ekstraksi gigi berdasarkan pengukuran VAS 


\begin{tabular}{ccccc}
\hline & \multicolumn{3}{c}{ Pemeriksaan fisik pengukuran } \\
& \multicolumn{3}{c}{ VAS } \\
\cline { 2 - 5 } Kategori & Sebelum & \multicolumn{2}{c}{ Sesudah } \\
& menghirup & menghirup \\
& aromaterapi & aromaterapi \\
& $\mathrm{n}$ & $\%$ & $\mathrm{n}$ & $\%$ \\
\hline 1 & 1 & 9 & 6 & 55 \\
2 & 6 & 55 & 4 & 36 \\
3 & 4 & 36 & 1 & 9 \\
4 & 0 & 0 & 0 & 0 \\
5 & 0 & 0 & 0 & 0 \\
6 & 0 & 0 & 0 & 0 \\
Total & 11 & 100 & 11 & 11 \\
\hline
\end{tabular}

Tabel 8. Distribusi gambaran kecemasan pasien yang pernah menjalani prosedur ekstraksi gigi berdasarkan pengukuran VAS

\begin{tabular}{ccccc}
\hline & \multicolumn{2}{c}{ Pengukuran VAS } \\
\cline { 2 - 5 } Kategori & \multicolumn{2}{c}{ Sebelum } & \multicolumn{2}{c}{ Sesudah } \\
& menghirup & \multicolumn{2}{c}{$\begin{array}{c}\text { menghirup } \\
\text { aromaterapi }\end{array}$} & \multicolumn{2}{c}{ aromaterapi } \\
& $\mathrm{n}$ & $\%$ & $\mathrm{n}$ & $\%$ \\
\hline 1 & 11 & 57,89 & 15 & 79 \\
2 & 5 & 26,31 & 4 & 21 \\
3 & 3 & 15,78 & 0 & 0 \\
4 & 0 & 0 & 0 & 0 \\
5 & 0 & 0 & 0 & 0 \\
6 & 0 & 0 & 0 & 0 \\
Total & 19 & 100 & 19 & 100 \\
\hline
\end{tabular}

Berdasarkan observasi yang dilakukan oleh peneliti, kecemasan yang dialami oleh operator sangat sulit untuk disembunyikan dihadapan pasien dan tidak menutup kemungkinan dapat mengakibatkan operator melakukan kesalahan yang dapat memicu rasa cemas pada pasien.

Tabel 9. Distribusi gambaran penurunan kecemasan pasien berdasarkan pemeriksaan fisik

\begin{tabular}{ccccc}
\hline \multirow{2}{*}{$\begin{array}{c}\text { Pemeriksaan } \\
\text { fisik }\end{array}$} & \multicolumn{2}{c}{$\begin{array}{c}\text { pasien yang } \\
\text { cemas }\end{array}$} & \multicolumn{2}{c}{$\begin{array}{c}\text { Penurunan } \\
\text { kecemasan }\end{array}$} \\
\cline { 2 - 5 } & $\mathrm{n}$ & $\%$ & $\mathrm{n}$ & $\%$ \\
\hline Tekanan & 2 & 100 & 2 & 100 \\
Darah & 8 & 100 & 7 & 87,5 \\
Denyut Nadi & 8 & 100 & 14 & 87,5 \\
Respirasi & 16 & & & \\
\hline
\end{tabular}

\section{BAHASAN}

Ekstraksi gigi adalah suatu tindakan kuratif dalam dunia kedokteran gigi yang umumnya menjadi pencetus timbulnya kecemasan. Selain prosedur ekstraksi, faktor lain yang dapat memicu timbulnya kecemasan pasien berasal dari kecemasan yang dirasakan oleh operator. Hal ini diungkapkan secara pribadi oleh beberapa operator yang hendak menangani pasien ekstraksi gigi di tempat penelitian berlangsung; beberapa operator merasa cemas ketika hendak menangani pasien.

Menurut Baart dan Brand (2008) terdapat beberapa komplikasi anastesi lokal pada saat pencabutan, salah satu yang sesuai dengan penelitian yang dilakukan oleh Fitria Sultan (2014) mengenai kesalahan operator adalah nyeri akibat kesalahan pada tahap anastesi yang mengakibatkan anastesi berulang. Nyeri yang terjadi dapat menyebabkan peningkatan kecemasan pasien dan dapat menciptakan gerakan tiba-tiba pada pasien. ${ }^{5}$ Faktor lain yang dapat memicu timbulnya kecemasan adalah tingkat kejenuhan atau perasaan bosan yang dirasakan oleh pasien. Pada penelitian ini, dijumpai seorang pasien yang pada semua tahapan pemeriksaan baik sebelum maupun sesudah menghirup aromaterapi lavender tidak menunjukkan adanya perubahan baik itu pada pengukuran evaluasi fisik tekanan darah, denyut nadi, dan respirasi maupun pada pengukuran VAS. Terlalu lama berada di ruang tunggu dan terlambat mendapat pelayanan menjadi faktor pasien merasa bosan yang ternyata memiliki pengaruh terhadap mood atau emosi pasien yang kemudian memiliki hubungan dengan tingkat kecemasan pasien.

Hasil dari pengukuran tekanan darah pasien yang belum pernah menjalani prosedur ekstraksi gigi pada Tabel 1. memperlihatkan tidak terdapat pasien yang cemas namun sejumlah 45\% pasien mengalami penurunan tekanan darah, sedangkan data pasien yang sebelumnya pernah menjalani prosedur ekstraksi gigi berdasarkan pengukuran tekanan darah pada Tabel 2. menunjukkan sejumlah $10.5 \%$ pasien mengalami kecemasan sebelum menghirup aromaterapi dan 
kecemasan tersebut mengalami penurunan sebanyak rata-rata 10 angka setelah menghirup aromaterapi. Hal ini membuktikan bahwa pengalaman menjalani ekstraksi gigi tidak dapat menjadi indikator menurunnya kecemasan yang dialami oleh pasien. Operator juga merupakan salah satu faktor yang memengaruhi kecemasan pasien. Hal ini disebabkan oleh pengelolaan yang kurang tepat dari operator. Pasien akan selalu memperhatikan perilaku operator setiap kali berkunjung ke dokter gigi sehingga kunjungan pasien memengaruhi perilaku pasien pada kunjungan berikutnya. ${ }^{6}$

Tabel 3 mengenai pengukuran denyut nadi menunjukkan dari 11 pasien yang belum pernah menjalani prosedur ekstraksi gigi, sebanyak $18,2 \%$ pasien mengalami kecemasan namun setelah menghirup aromaterapi lavender 9,1\% pasien tidak lagi mengalami cemas dan 9,1\% lainnya mengalami penurunan kecemasan sebanyak 2 denyut/menit. Sekitar 72,3\% pasien yang tidak mengalami kecemasan sebelum menghirup aromaterapi lavender mengalami penurunan frekuensi denyut nadi dengan rata-rata penurunan 4,5 denyut nadi/menit.

Tabel 4 mengenai pengukuran denyut nadi pasien yang pernah menjalani prosedur ekstraksi gigi, dari 19 pasien sejumlah $31,6 \%$ pasien mengalami kecemasan sebelum menghirup aromaterapi lavender namun setelah menghirup aromaterapi lavender, 21,1\% pasien tidak lagi mengalami kecemasan dan 10,5\% pasien lainya mengalami penurunan kecemasan rata-rata 4 denyut/menit. 68,4\% pasien yang tidak mengalami kecemasan sebelum menghirup aromaterapi lavender mengalami penurunan frekuensi denyut nadi dengan rata-rata penurunan 7,5 denyut/menit.

Beatrix (2014) dalam penelitian tentang hubungan tingkat kecemasan dengan perubahan denyut nadi pada pasien ekstraksi mengatakan bahwa terjadinya peningkatan denyut nadi dikarenakan ada ketakutan dalam diri pasien dengan peralatan ekstraksi dan resiko yang akan terjadi saat ekstraksi gigi berlangsung. ${ }^{7}$

Tabel 5 mengenai pengukuran respirasi menunjukkan dari 11 pasien yang belum pernah menjalani prosedur ekstraksi gigi, sebanyak 45,5\% pasien mengalami kecemasan namun setelah menghirup aromaterapi lavender 27,3\% pasien tidak lagi mengalami cemas dan 9,1\% mengalami penurunan kecemasan. 36,4\% pasien yang tidak mengalami kecemasan sebelum menghirup aromaterapi lavender mengalami penurunan respirasi dengan rata-rata penurunan 5,3 kali/menit.

Pengukuran respirasi pada pasien yang sebelumnya sudah pernah menjalani eksraksi gigi pada Tabel 6 menunjukkan bahwa sebelum menghirup aromaterapi lavender dari 19 pasien sejumlah 57,9\% pasien mengalami kecemasan sebelum menghirup aromaterapi lavender namun setelah menghirup aromaterapi lavender, $26,3 \%$ pasien tidak lagi mengalami kecemasan dan 26,3\% pasien lainnya mengalami penurunan kecemasan rata-rata 3 kali/menit. 10,5\% pasien yang tidak mengalami kecemasan sebelum menghirup aromaterapi lavender mengalami penurunan respirasi dengan rata-rata penurunan 3,5kali/menit.

Pengukuran berdasarkan VAS pada Tabel 7 pada pasien yang belum pernah menjalani ekstraksi gigi sebelum menghirup aromaterapi lavender menunjukkan sejumlah 55\% pasien mengalami kecemasan ringan turun menjadi tidak ada rasa cemas sejumlah $36,36 \%$ pasien setelah menghirup aromaterapi lavender, sejumlah $36 \%$ pasien mengalami kecemasan yang tidak menyenangkan turun menjadi rasa cemas ringan sejumlah 18,18\% pasien, dan 9\% tidak mengalami kecemasan. Aromaterapi lavender dipercaya secara fisik baik digunakan untuk mengurangi nyeri dan menenangkan, sedangkan secara psikologi dapat merilekskan pikiran, menurunkan ketegangan dan kecemasan (Mackinon, 2004). ${ }^{8}$

Penggunaan terapi menggunakan aromaterapi lavender untuk mengatasi kecemasan pasien berdasarkan pengukuran VAS bagi pasien yang sudah pernah 
menjalani ekstraksi gigi pada Tabel 8 menunjukkan bahwa sebelum menghirup aromaterapi lavender sejumlah 26,31\% pasien mengalami kecemasan ringan dan $15,78 \%$ pasien mengalami kecemasan yang tidak menyenangkan, namun menurun sejumlah 26,31\% pasien dari rasa cemas ringan menjadi tidak ada rasa cemas, $10,52 \%$ pasien dari rasa cemas yang tidak menyenangkan menjadi tidak ada rasa cemas, dan sejumlah 5,26\% pasien dari rasa cemas yang tidak menyenangkan menjadi rasa cemas ringan setelah menghirup aromaterapi lavender.

Tabel 9 menunjukkan dari 30 pasien yang menjalani ekstraksi gigi sebelum menghirup aromaterapi lavender pada pemeriksaan tekanan darah sejumlah $6,7 \%$ pasien mengalami kecemasan namun setelah menghirup aromaterapi lavender semuanya mengalami penurunan kecemasan rata-rata 10 angka. Pada pengukuran denyut nadi, sejumlah $26,7 \%$ pasien mengalami kecemasan sebelum menghirup aromaterapi lavender namun $16,6 \%$ tidak lagi merasa cemas sesudah menghirup aromaterapi lavender dan 6,7\% lainnya mengalami penurunan kecemasan rata-rata 4 denyut. Pada pengukuran respirasi sejumlah 53,3\% pasien mengalami kecemasan sebelum menghirup aromaterapi lavender namun sesudah menghirup aromaterapi lavender, 23,3\% pasien tidak merasa cemas lagi dan 23,3\% lainnya mengalami penurunan kecemasan rata-rata $2,8 \mathrm{kali} /$ menit.

Hasil penelitian pada Tabel 9 sama halnya dengan beberapa hasil penelitian yang dirangkum oleh Dewi (dkk) dalam penelitian tentang pengaruh pemberian aromaterapi terhadap tingkat kecemasan pasien gagal ginjal kronik yang menjalani hemodialisis menyatakan bahwa salah satu kandungan dalam minyak essensial dapat memengaruhi aktivitas fungsi kerja otak melalui sistem saraf yang berhubungan dengan indera penciuman. Respon ini akan merangsang peningkatan neurotransmitter yang berkaitan dengan pemulihan kondisi psikologis seperti emosi, perasaan, pikiran, dan keinginan. $^{2}$
Kandungan linalool asetat sebagai bahan aktif utama yang terkandung dalam minyak essensial lavender dinilai mampu mengendurkan dan melemaskan sistem kerja saraf dan otot-otot yang tegang dengan cara menurunkan kerja dari saraf simpatis saat seseorang mengalami kecemasan (Rahayu dkk, 2007). Saraf simpatis yang membawa serabut saraf vasokonstriksor akan mengalami penurunan kinerja saat linalool asetat masuk masuk kedalam tubuh. Kondisi ini mengakibatkan menurunnya produksi epinefrin yang dikeluarkan oleh ujungujung saraf vasokonstriksor sehingga gejala kecemasan seperti peningkatan tekanan darah, frekuensi denyut nadi dan respirasi mengalami penurunan. ${ }^{2}$

\section{SIMPULAN}

Pasien yang akan menjalani ekstraksi gigi mengalami kecemasan sebelum menghirup aromaterapi dan kecemasan tersebut mengalami penurunan setelah menghirup aromaterapi berdasarkan evaluasi fisik dan pengukuran VAS. Menghirup Aromaterapi lavender dapat menurunkan frekuensi tekanan darah, denyut nadi, dan respirasi pada pasien yang menjalani ekstraksi gigi.

\section{SARAN}

1. Diharapkan masyarakat dapat menggunakan aromaterapi lavender sebagai pilihan praktis untuk mengatasi kecemasan ketika menjalani tindakan ekstraksi gigi.

2. Penelitian ini diharapkan menjadi referensi sebagai salah satu solusi bagi pihak RSGM PSPDG FK Unsrat Manado dalam upaya meningkatkan pelayanan terutama dalam bidang pencabutan gigi terkait dengan masalah kecemasan pasien.

3. Rasa cemas yang dialami oleh operator dalam melakukan perawatan gigi khususnya ekstraksi gigi merupakan masalah yang perlu dicari jalan keluarnya. Penelitian lanjutan mengenai kecemasan operator terhadap kecemasan pasien dan cara 
menanggulangi dapat dilakukan.

\section{DAFTAR PUSTAKA}

1. Pedersen GW. Buku ajar praktis bedah mulut. Alih bahasa: Purwanto, Basoeseno. Jakarta: EGC; 1996. p.2931,99-103,117-8.

2. Dewi, I Putu Pasuana Putra, I Made Surata Witarsa. Pengaruh aromaterapi inhalasi terhadap penurunan tingkat kecemasan pasien gagal ginjal kronik yang menjalani hemodialisis di RSUD Wangaya Denpasar. Universitas Udayana [serial online] 2013: [internet]. Available from : https://scholar.google.co.id/scholar?bi $\mathrm{w}=1366 \& \mathrm{bih}=623 \&$ noj $=1$ \&um $=1$ \&ie $=$ UTF-8\&Ir\&q=related:7Tq67amhfV8hM:scholar.google.com/

3. Arwani. Pengaruh pemberian aromaterapi terhadap tingkat kecemasan pasien sebelum operasi dengan anastesi spinal di RS Tugu Semarang. Jurnal keperawatan jiwa. 2013;1:129-34.

4. Kristanti EE. Pengaruh aromaterapi lavender terhadap penurunan derajat kecemasan pada lansia di panti Wredha st.Yoseph Kediri. Jurnal stikes RS.Baptis Kediri 2010; 3: 94-9.

5. Sultan F. Prevalensi terjadinya kesalahan operator pada tindakan ekstraksi gigi di RSGM Kandea. Makassar: Universitas Hasanuddin:2014.p. 20.

6. Permatasari AS. Pola perilaku anak terhadap perawatan gigi dan mulut. Makassar: Universitas Hasanuddin; 2014.p. 37.

7. Pontoh B, Pangemanan DHC, Ni Wayan Mariati. Hubungan tingkat kecemasan dengan perubahan denyut nadi pada pasien ekstraksi gigi di puskesmas Tuminting Manado. Jurnal e-GiGi. 2015;3:15.

8. Widyastuti Y. Efektivitas aromaterapi lavender dalam menurunkan nyeri dan kecemasan pasien pre operasi fraktur femur di RS Ortopedi Prof. Dr. R. Soeharso Surakarta. Prosiding Konferensi Nasional PPNI Jawa Tengah 2013; p. 92-4. 